\title{
RESPON GURU SEKOLAH DASAR \\ TERHADAP PENGGUNAAN BUKU GURU \\ DALAM IMPLEMENTASI KURIKULUM 2013
}

\author{
1Oleh: \\ Rudi Susilana (rudi_susilana@upi.edu) \\ Muthia Alinawati (melati.muthia@gmail.com)
}

\begin{abstract}
To see the effectiveness of the use of the book, this study examines how the response of teachers, especially primary school teachers to use in the implementation of the Curriculum Master Books, 2013, particularly with respect to one of the main teacher's main task, which is preparing Learning Implementation Plan (RPP). The subjects were elementary school teachers who participated in the Training Curriculum 20132014 originating from various districts / cities in West Java Province. Teachers were randomly selected and acquired research subject as many as 150 people. The conclusions of this study are (1) The response of primary school teachers to use in preparing the Master Books Learning Implementation Plan (RPP) on the implementation of Curriculum2013 in the category generally positive and very positive; (2) There is no difference in the response of teachers to use Teachers guide in developing and preparing les son plans Thematic visits of regional differences as signment (districts); and (3) There are differences in the response of teachers to use of Books Teachers develop and prepare lesson plans Thematic views of component materials / learning experience, component methods / lesson, and components of the assessment, but there are differences in the response of teachers to use of Books Teachers develop and prepare les
\end{abstract}

Keywords: Implementation of Curriculum 2013, Master Books, Response Teacher..

${ }^{1}$ Rudi Susilana a dalah Dosen Jurusan Kurikulum dan Teknologi Pendidikan Muthia Al inawati adalah Dosen Jurusan Kurikulum dan Teknologi Pendidikan 
PENDAHULUAN

Kebijakan implementasi Kurikulum 2014 telah menjadi keputusan Pemerintah dengan lahirnya Permendikbud No. 81A Tahun 2013 tentang Implementasi Kurikulum dan peraturan-peraturan lain yang mendukung. Saat ini implementasi Kurikulum 2013 telah dilaksanakan secara bertahap dan menyeluruh di berbagai satuan pendidikan. Implementasi diawali pada tahun 2013 dengan sasaran siswa kelas $1 \mathrm{SD} / \mathrm{MI}$, kelas 4 SD/MI, kelas 1 SMP/MTs, dan kelas 1 SMU/MA/SMK, kemudian dilanjutkan dengan kelas $2 \mathrm{SD} / \mathrm{MI}$, kelas 5 SD/MI, kelas 2 SMP/MTs, dan kelas 2 SMU/MA/SMK, dan terakhir kelas $3 \mathrm{SD} / \mathrm{MI}$, kelas $6 \mathrm{SD} / \mathrm{MI}$, kelas 3 SMP/MTs, dan kelas 3 SMU/MA/SMK Dalam implementasi Kurikulum 2013 terdapat beberapa hal penyempurnaan dan perubahan. Diantara berbagai perubahan yang ada, satu diantaranya terkait dengan kebijakan penggunaan Buku Guru (BG) dan Buku Siswa (BS) dalam implementasi Kurikulum 2013. Berbeda dengan kebijakan yang terjadi pada implementasi kurikulum sebelumnya, pada implementasi Kurikulum 2013, penggunaan Buku Guru dan Buku Siswa menjadi buku teks yang wajib digunakan di seluruh Indonesia. Sebagaimana telah dinyatakan oleh Mendikbud, Muhammad Nuh, bahwa Kemendikbud telah menyusun buku pegangan untuk guru dan siswa dalam implementasi Kurikulum 2013. Rencananya, tanggung jawab buku tersebut akan terpusat pada tim penyusun yang dibentuk khusus. Mendikbud menegaskan bahwa kebijakan pertanggungjawaban terpusat atas buku pegangan guru dan siswa diimplementasikan untuk menanggulangi kesalahan penerbitpenerbit buku pelajaran. Selain itu, kata Mendikbud, dengan ditetapkannya satu buku acuan bagi peserta didik, maka akan meringankan siswa-siswi sendiri dalam membeli buku. Selama ini siswa-siswi masih dibebani dengan buku Lembar Kerja Siswa (LKS) yang harus dibeli terpisah. Semua peserta didik pada setiap jenjang menggunakan buku teks yang sama. Guru pun dibekali buku pegangan yang sama. Strategi, metode, model, bahkan langkah-langkah pembelajarannya sudah tersusun secara rinci dalam buku pegangan itu. Guru hanya tinggal melaksanakan apa yang tersurat dalam buku pegangan. Peserta didik di seluruh wilayah nusantara pun mendapatkan "asupan" materi pembelajaran dan soal-soal uji kompetensi yang sama dalam buku teks (http://sawali.info/2012/12/07/posisibuku-teks-dalam-rancangan-

kurikulum-2013/).

Dalam laman kemdikbud juga ditegaskan bahwa "Buku teks pelajaran pada implementasi Kurikulum 2013 Tahun Pelajaran 2014/2015 untuk kelas 1,2,4,5,7,8,10, dan 11, disediakan oleh pemerintah. Pengadaan buku ini dianggarkan lewat APBN yang dialokasikan melalui dana bantuan operasional sekolah (BOS) dan BOS Buku" (http://kemdikbud.go.id/ kemdikbud/berita/2817). Kepala Pusat Informasi dan Humas Kemdikbud, Ibnu Hamad, menjelaskan bahwa dengan mekanisme tersebut, orang tua tidak lagi dibebani pembelian buku jelang dimulainya tahun pelajaran baru. Namun demikian, Kemdikbud mengimbau orang tua untuk tetap waspada terhadap beredarnya buku teks pelajaran tiruan yang tidak dicetak oleh penerbit pemenang lelang pengadaan buku Kurikulum 2013. "Buku dari Kemdikbud tidak diperjualbelikan ke orang tua, dengan dana BOS itu sekolah yang membeli langsung ke penyedia," kata Ibnu pada gelar wicara dengan Radio Sindo Trijaya, Selasa (8/07), di Kantor Kemdikbud. 
Adanya kebijakan di atas, menurut Hamdani, ada beberapa persoalan yang mungkin dihadapi, yaitu: "Pertama, penggunaan buku paket yang hanya berlaku untuk satu tahun jelas bertentangan dengan Peraturan Menteri No 11 tahun 2005 tentang buku teks pelajaran yang digunakan disekolah. Dalam pasal 7 ayat 1 disebutkan bahwa buku teks pelajaran yang digunakan di sekolah dasar dan menengah berlaku paling sedikit lima tahun. Kedua, penggunaan buku teks pelajaran yang hanya berlaku untuk satu tahun dan setelah itu dicetak ulang karena isinya akan berbeda memunculkan kesan bahwa kurikulum baru yang akan diterapkan mulai tahun ajaran ini belum matang. ...Ketiga, proses cetak ulang buku teks pelajaran yang akan dilakukan setiap tahun dikhawatirkan hanya akan memboroskan anggaran negara disamping akan menguntungkan pihak-pihak tertentu..." (http://guraru.org/guru-berbagi/bukuajar-dalam-kurikulum-2013).

Terlepas dari kebijakan baru dalam pengembangan dan pengadaan buku yang telah ditetapkan Pemerintah. Buku, khususnya buku teks pelajaran, memiliki peranan penting dalam implementasi kurikulum. Buku merupakan salah satu sumber belajar dan menjadi komponen wajib yang harus ada di lembaga pendidikan, khususnya sekolah/ madrasah. Terdapat berbagai jenis buku yang dapat digunakan dalam pembelajaran. Ada dua kategori besar, yaitu: buku teks pelajaran dan buku nonteks pelajaran. Buku teks pelajaran adalah buku-buku yang disusun secara serial berdasarkan tingkatan kelas dan dikembangkan sesuai dengan kompetensi yang terdapat dalam standar isi setiap mata pelajaran, sedangkan buku nonteks pelajaran adalah buku yang dikembangkan untuk menambah pengetahuan dan wawasan peserta didik dan pendidik. Buku nonteks pelajaran dapat berupa buku panduan pendidik, buku pengayaan, dan buku referensi (Permendiknas Nomor 2 Tahun 2005 tentang Buku).

Untuk mendukung implementasi Kurikulum 2013 telah dikembangkan Buku Guru (BG) dan Buku Siswa (BS). BG merupakan buku panduan yang dipersiapkan untuk memandu guru melaksanakan pembelajaran dan BS merupakan buku yang dipersiapkan untuk siswa melakukan berbagai aktivitas belajar, yang sekaligus berfungsi sebagai lembar kerja. Oleh karena itu untuk melihat efektivitas penggunaan buku tersebut, penelitian ini ingin mengkaji tentang bagaimanakah respon guru, khususnya guru SD, terhadap penggunaan Buku Guru dalam implementasi Kurikulum 2013, khususnya terkait dengan salahsatu tugas guru, yaitu menyusun Rencana Pelaksanaan Pembelajaran (RPP).

Berdasarkan latar belakang tersebut, dirumuskan masalah penelitian sebagai berikut.

1. Bagaimanakah respon guru SD terhadap penggunaan Buku Guru dalam mengembangkan komponen kompetensi atau tujuan pembelajaran pada penyusunan RPP Kurikulum 2013?

2. Bagaimanakah respon guru SD terhadap penggunaan Buku Guru dalam mengembangkan komponen materi atau pengalaman belajar pada penyusunan RPP Kurikulum 2013?

3. Bagaimanakah respon guru SD terhadap penggunaan Buku Guru dalam mengembangkan komponen metode atau kegiatan pembelajaran pada penyusunan RPP Kurikulum 2013?

4. Bagaimanakah respon guru SD terhadap penggunaan Buku Guru dalam mengembangkan komponen penilaian pada penyusunan RPP Kurikulum 2013? 
5. Apakah terdapat perbedaan respon guru terhadap penggunaan Buku Guru dalam mengembangan dan menyusun RPP Tematik dilihat dari perbedaan daerah penugasan?

6. Apakah terdapat perbedaan respon guru terhadap penggunaan Buku Guru mengembangan dan menyusun RPP Tematik dilihat dari komponen RPP?

\section{KAJIAN TEORI}

\section{Kedudukan Materi atau Bahan Ajar dalam Kurikulum}

Dalam buku kecilnya, "Basic Principles of Curriculum and Instruction" (1975:1), Tyler mengajukan Four-Step Model sebagai tahapan dalam mengembangkan kurikulum, yaitu: Pertama, tujuan pendidikan seperti apa yang harus dicapai oleh sekolah; Kedua, pengalaman belajar seperi apa yang harus diberikan untuk mencapai tujuan tersebut; Ketiga, bagaimanakah mengorganisasikan pengalaman belajar agar efektif?; dan keempat, bagaimana agar dapat menentukan bahwa tujuan tersebut telah tercapai?. Sejalan dengan hal tersebut, Zais mengemukakan anatomy of the curriculum yang menjelaskan empat komponen kurikulum yang terdiri atas: aims; goals; objectives, content, learning activities, dan evaluation (Zais, 1976: part III). Sedangkan Giles dalam Ornstein \& Hunkins (1998;166) lebih ringkas menjelaskan bahwa terdapat empat komponen dalam pengembangan kurikulum yang terdiri atas "objectives, subject matter, method and organization, evalution". Berdasarkan pendapat di atas, "subject matter" atau "content" merupakan komponen utama dalam pengembangan kurikulum. Secara makro, konten kurikulum ini berkaitan dengan kegiatan memilih, menilai, dan menentukan jenis bidang keilmuan atau mata pelajaran apa yang harus diajarkan pada suatu jenis dan jenjang persekolahan (lembaga pendidikan), kemudian pokok bahasan, sub pokok bahasan dan rincian materi, termasuk ruang lingkup (scope) dan urutan (sequence). Adapun patokan kegiatan tersebut ditentukan oleh tujuan-tujuan dari jenis dan jenjang sekolah yang bersangkutan. Adapun secara khusus, yang dimaksud dengan konten kurikulum adalah segala sesuatu yang diberikan kepada siswa dalam kegiatan belajar mengajar. Isi dari kegiatan tersebut adalah isi dari kurikulum. Isi atau bahan tersebut tersusun berbagai program pendidikan berdasarkan jenis dan jenjang sekolah, kemudian dikemas dalam berbagai bidang studi atau mata pelajaran yang kemudian dijabarkan dalam pokok dan sub pokok bahasan, yang secara lebih rinci disusun dalam bentuk bahan pengajaran (bahan ajar/ materi pelajaran) dalam berbagai bentuknya. Tugas guru adalah mengembangkan bahan ajar tersebut berdasarkan tujuan pembelajaran atau kompetensi yang telah disusun dan dirumuskan sebelumnya.

\section{Buku Guru dalam Implementasi Kurikulum 2013}

Berbeda dengan kebijakan sebelumnya, pada implementasi Kurikulum 2013, penggunaan Buku Guru dan Buku Siswa menjadi buku yang wajib digunakan di seluruh Indonesia. BG dan BS pada Kurikulum 2013 dirancang sedemikan rupa untuk mendukung keterlaksanaan impelementasi kurikulum dengan baik.

\section{a. Kedudukan dan Fungsi Buku Guru \\ Dalam implementasi Kurikulum 2013, Buku Guru atau BG}


merupakan buku panduan yang harus digunakan ketika guru melaksanakan pembelajaran di kelas. Penggunaan BG menjadi wajib digunakan karena telah dirancang untuk menjadi pasangan Buku Siswa atau BS.

BG memiliki fungsi sebagai (1) Petunjuk penggunaan buku siswa (BS), (2) Acuan kegiatan pembelajaran, dan (3) Penjelasan tentang metode dan teknik pembelajaran yang digunakan dalam proses pembelajaran.

Lebih rinci dalam Buku Materi Pelatihan Kurikulum 2013 Untuk Jenjang SD (2014:42-43) dipaparkan sebagai berikut.

Sebagai petunjuk penggunaan Buku Siswa, seorang guru harus mempelajari terlebih dahulu Buku Guru dan harus menemukan informasi sebagai berikut.

1) Urutan acuan materi pelajaran yang dikembangkan dari Standar Kompetensi Lulusan, Kompetensi Inti, dan Kompetensi Dasar dari masing-masing muatan pelajaran, yang kemudian dipadukan dalam satu tema tertentu.

2) Jaringan tema dari masingmasing tema yang berisi kompetensi dasar dan indikator dari masing-masing muatan pelajaran yang harus dicapai.

3) Pemilahan pembelajaran yang dikembangkan dari subtema dengan tujuan agar guru secara bertahap dapat menyelenggarakan proses pembelajaran yang sesuai dengan kompetensi dasar yang harus dikuasai siswa.

Sebagai Acuan Kegiatan Pembelajaran di Kelas, Buku
Guru menyajikan hal-hal sebagai berikut.

1) Menjelaskan tujuan pembelajaran yang harus dicapai pada setiap pilahan pembelajaran dari masingmasing subtema.

2) Menjelaskan media pembelajaran yang dapat digunakan dalam menyelenggarakan proses pembelajaran agar guru sudah menyiapkan mediamedia pembelajaran yang diperlukan.

3) Menjelaskan langkahlangkah pembelajaran yang dilakukan dalam menyelenggarakan proses pembelajaran agar dapat membantu guru dalam menyusun rencana pelaksanaaan pembelajaran, dengan sistematis mengikuti langkah-langkah pembelajaran tersebut.

4) Menjelaskan tentang teknik dan instrumen penilaian yang dapat digunakan dalam setiap pilihan pembelajaran yang mungkin memiliki karakteristik tertentu.

5) Menjelaskan jenis lembar kerja yang sesuai dengan pilahan pembelajaran yang ada dalam Buku Siswa.

Sebagai Penjelasan tentang Metode dan Teknik Pembelajaran yang Digunakan dalam Proses Pembelajaran, Buku Guru memuat informasi tentang model dan strategi pembelajaran yang digunakan sebagai acuan penyelenggaraan proses pembelajaran.

\section{b. Struktur Buku Guru}

Selanjutnya dalam Buku Materi Pelatihan Kurikulum 2013 (2014:44-45) diuraikan tentang 
strktur Buku Guru. Guru wajib mengenal dan memahami struktur isi Buku Guru dengan baik. Struktur Buku Guru dirancang sebagai berikut.

1) Kata Pengantar

Kata pengantar berisi tentang latar belakang penyusunan buku dan tujuan yang ingin dicapai dari penyusunan buku tersebut.

2) Tentang Buku Guru

Bagian ini memaparkan informasi tentang cakupan buku guru dan cakupan aktivitas pembelajaran.

3) Bagaimana Menggunakan Buku Guru

Bagian ini memberikan informasi hal-hal penting yang harus diperhatikan dengan seksama oleh guru dalam menggunakan Buku Guru sebagai persiapan menggunakan Buku Siswa.

4) Panduan Penilaian

Bagian ini berisi informasi teknik dan instrumen penilaian, dan contoh-contoh rubrik penilaian yang akan digunakan/ dikembangkan oleh guru dalam melakukan evaluasi proses pembelajaran. Guru harus memahani bahwa Kurikulum 2013 menggunakan pendekatan penilaian otentik.

5) Standar Kompetensi Lulusan dan Kompetensi Inti

Bagian ini berisi standar kompetensi lulusan (SKL), baik ranah sikap, keterampilan, dan pengetahuan, serta kompetensi inti setiap kelas, yang harus dicapai selama proses pembelajaran.

6) Pemetaan Kompetensi Dasar KI 1 dan KI 2
Pemetaan KD pada KI 1 dan KI 2 merupakan Pemetaan KD yang berasal dari KI 1 dan KI 2 yang terdapat dalam setiap subtema. Artinya, KD inilah yang semestinya dicapai dalam proses pembelajaran selama satu minggu.

7) Pemetaan Kompetensi Dasar KI 3 dan KI 4

Pemetaan KD pada KI 3 dan KI 4 merupakan Pemetaan KD yang berasal dari KI 3 dan KI 4. Bagian ini memuat informasi tentang kompetensikompetensi yang berasal dari Pemetaan Kompetensi Inti 3 dan 4 yang harus dicapai dalam satusubtema pembelajaran. Dijelaskan lebih rinci bahwa "Penetapan kompetensi masih terbuka untuk penggantian atau penambahan sesuai dengan kegiatan yang dirancang oleh guru. Sekali lagi guru harus memahami bahwa pembelajaran tematik terpadu itu berbasis aktivitas sehingga aktivitas yang ditawarkan di dalam buku guru bisa diganti atau dikembangkan sesuai dengan kreativitas guru".

8) Ruang Lingkup Pembelajaran Bagian ini memberikan gambaran ringkas tentang kegiatan yang akan dilaksanakan oleh guru dan kemampuan yang akan dikembangkan dalam setiap pembelajaran. Kolom kegiatan pembelajaran menjelaskan kegiatan yang dilakukan pada satu hari pembelajaran. Kolom kemampuan yang dikembangkan menjelaskan tiga aspek kemampuan yang harus dicapai, yaitu sikap, 
pengetahuan,

dan

keterampilan.

9) Halaman Pembelajaran

Setiap pembelajaran terdiri atas bagian-bagian yang menuntun guru dalam proses pembelajaran yang disesuaikan dengan buku siswa. Jika mengacu pada Struktur Kurikulum 2013 jenjang SD, jumlah jam pelajaran di kelas 1 adalah 30 jam pembelajaran/minggu. Pembagian 30 jam/minggu dalam pembelajaran disesuaikan dengan kondisi sekolah. Pada buku siswa dan buku guru, kegiatan pembelajaran dibagi menjadi 6 pembelajaran dalam seminggu. Artinya, pembagian itu diasumsikan untuk 6 hari sekolah dalam seminggu. Sekolah yang menerapkan 5 hari sekolah, kompetensi dasar pada pembelajaran 6 dapat disebar ke 5 pembelajaran yang lain.Uraian pembelajaran diawali dengan judul pembelajaran sesuai nomor pembelajaran, misalnya Pembelajaran 1, Pembelajaran 2, Pembelajaran 3, dan seterusnya.

Selain itu, dalam Buku Guru terdapat bagian-bagian yang juga penting untuk dipahami. Bagianbagian dari uraian pembelajaran berisi tentang hal-hal sebagai berikut (Buku Materi Pelatihan Kurikulum 2013, 2014: 45).

\section{METODE PENELITIAN}

Subjek penelitian ini adalah guru SD yang menjadi peserta Diklat Kurikulum 2013 Tahun 2014 yang berasal dari berbagai kabupaten/ kota di Provinsi Jawa Barat. Guru dipilih secara acak dan diperoleh subjek penelitian sebanyak 150 orang.
Metode yang digunakan dalam penelitian ini adalah metode survei. Metode ini dipilih dengan alasan bahwa metode ini tepat digunakan untuk mendeskripsikan berbagai fenomena, mengeksplorasi dan menjelaskan ada tidaknya hubungan antar berbagai variabel berdasarkan data empirik. Sebagaimana Ali (2010: 48-49) menjelaskan sebagai berikut: "...Dalam riset pendidikan, survai bukan semata-mata dilakukan untuk mengumpulkan data atau informasi, seperti tentang pendapat atau sikap, tetapi juga untuk membuat deskripsi komprehensif maupun untuk menjelaskan hubungan antar berbagai variabel yang diteliti".

Instrumen yang digunakan dalam penelitian ini berupa daftar isian tertutup dan isian terbuka. Isian tertutup berupa pertanyaan yang telah disiapkan pilihan jawabannya, sedangkan isian terbuka berupa pertanyaan yang meminta jawaban terbuka dari responden. Pernyataan dan pertanyaan yang disajikan dalam instrumen penelitian terkait dengan komponen RPP, yaitu: kompetensi/ tujuan, materi/ pengalaman belajar, metode/ langkah-langkah kegiatan pembelajaran, dan penilaian.

Pengumpulan data dalam kegiatan penelitian dilakukan melalui penyebaran dan pengisian daftar isian sebagai instrumen pengumpul data kepada subjek penelitian pada kegiatan Diklat Kurikulum 2014 yang dilaksanakan di P4TK BMTI, P4TK IPA, dan LPMP Provinsi Jawa Barat.

Analisis data untuk mengolah data hasil penelitian mengggunakan statistik deskriptif berupa perhitungan prosentase dan uji beda dengan statistik nonparametrik dari Kruskal-Wallis. Statistik deskriptif digunakan untuk menggambarkan respon secara umum dan uji beda digunakan melihat ada tidaknya perbedaan respon berdasarkan daerah penugasan dan komponen RPP. 


\section{DESKRIPSI HASIL PENELITIAN DAN PEMBAHASAN}

\section{Deskripsi Hasil Penelitian}

Sebagaimana telah dipaparkan di bab sebelumnya bahwa subjek penelitian ini adalah guru SD yang menjadi peserta Diklat Kurikulum 2013 Tahun 2014. Guru SD tersebut berasal enam kabupaten/ kota, yaitu: Kabupaten Bandung, Kabupaten Bogor, Kabupaten Cirebon, Kabupaten Kuningan, Kabupaten Majalengka, dan KabupatenTasikmalaya. Dari hasil pengumpulan data diperoleh subjek penelitian yang mengisi dan mengumpulkan instrumen sebanyak 109 orang dari 150 orang yang direncanakan.

Untuk memudahkan penyajian deskripsi hasil penelitian ini disajikan menjadi dua bagian, yaitu: Respron Guru per Kabupaten dan Respon Guru per Komponen RPP. a. Respon Guru per Kabupaten

Respon guru SD terhadap penggunaan Buku Guru dalam menyusun Rencana Pelaksanaan Pembelajaran (RPP) pada implementasi Kurikulum 2013 per kabupaten dapat dikategorikan positif. Hal ini ditunjukkan dengan rata-rata respon guru terhadap Buku Guru sebanyak 27\% pada kategori membantu dan memudahkan (MM), $40 \%$ sangat membantu dan memudahkan (SMM), dan 30\% sangat membantu dan sangat memudahkan (SMSM). Dari enam kabupaten yang menjadi sampel, respon guru dari Kabupaten Bogor (44\% SM dan 38\% SMSM) dan Kuningan (43\% SMM dan $41 \%$ SMSM) yang lebih positif dibandingkan dengan kabupaten lainnya.

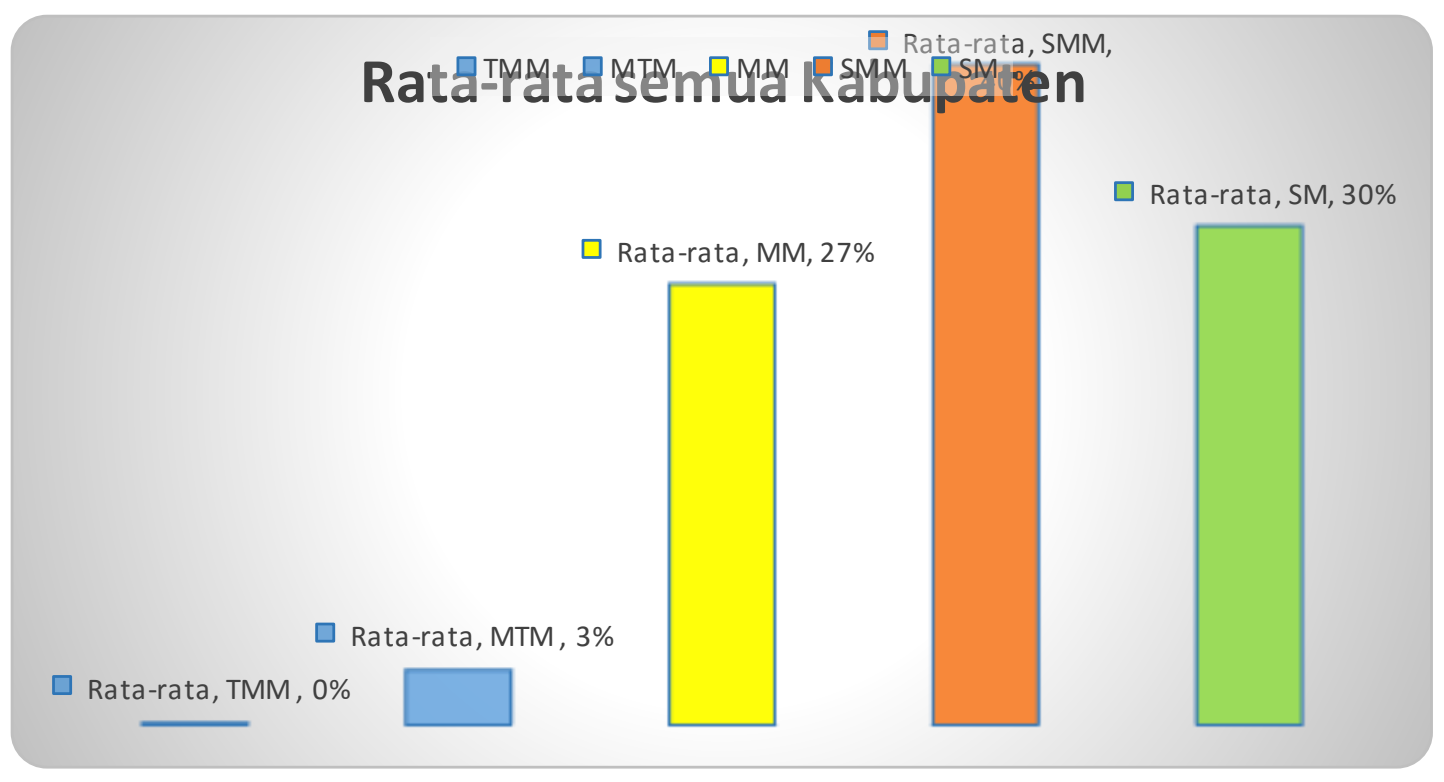

Gambar 1 Respon Guru terhadap Buku Guru per Kabupaten

Keterangan:

TMM = Tidak membantu dan tidak memudahkan

MTM = Membantu tetapi tidak memudahkan 
MM

= Membantu dan memudahkan

SMM = Sangat membantu dan memudahkan

Berdasarkan gambar di atas dan dilihat dari rata-rata respon, kategori SMM (40\%) merupakan kategori yang banyak dipilih oleh para guru di setiap kabupaten dan SMSM (30\%) merupakan kategori kedua yang banyak dipilih. Hal ini menunjukkan bahwa respon guru terhadap Buku Guru mememiliki kecenderungan positif dan sangat positif.

b. Respon Guru per Komponen RPP

Respon guru SD terhadap penggunaan Buku Guru dalam menyusun Rencana Pelaksanaan Pembelajaran (RPP) pada implementasi Kurikulum 2013 per komponen disajikan menjadi empat, yaitu: (a) respon komponen kompetensi/ tujuan pembelajaran, (b) respon komponen materi/ pengalaman belajar, (c) respon komponen metode/ langkah
SMSM = Sangat membantu dan sangat memudahkan atau SM (dalam grafik)

pembelajaran, dan (d) respon komponen penilaian.

1) Respon Komponen Kompetensi/ Tujuan Pembelajaran

Respon guru SD terhadap penggunaan Buku Guru dalam menyusun Rencana Pelaksanaan Pembelajaran (RPP) pada implementasi Kurikulum 2013 pada komponen kompetensi/ tujuan pembelajaran dapat dikategorikan positif. Hal ini ditunjukkan dengan rata-rata respon guru terhadap Buku Guru sebanyak $27 \%$ pada kategori MM, 38\% sangat SMM, dan $31 \%$ SMSM. Dari enam kabupaten yang menjadi sampel, respon guru dari Kabupaten Bogor (40\% SMM dan 40\% SMSM) dan Kuningan (42\% SMM dan 32\% SMSM) yang lebih positif dibandingkan dengan kabupaten lainnya pada komponen kompetensi/ tujuan pembelajaran.

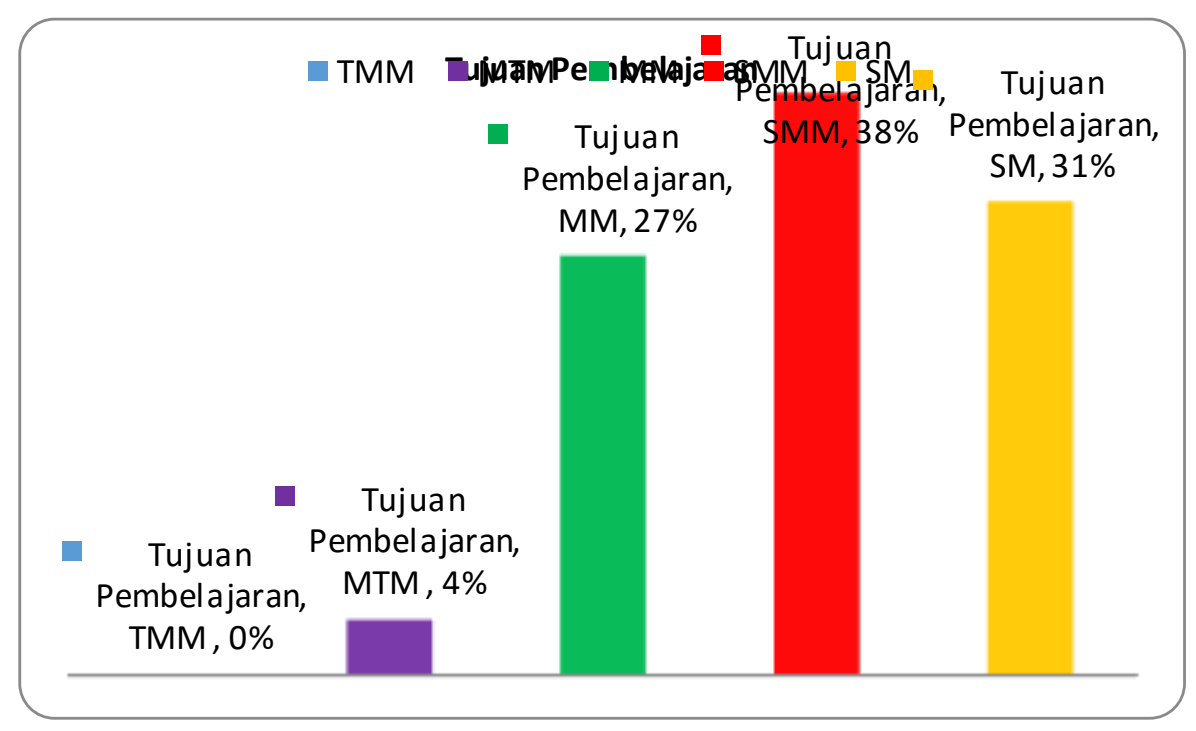

Gambar 2 Respon Guru terhadap Buku Guru pad

a Komponen Kompetensi/ Tujuan

Pembelajarn

Berdasarkan gambar di atas dan dilihat dari rata-rata respon, kategori SMM (38\%) merupakan kategori yang banyak dipilih oleh para guru pada komponen kompetensi/ tujuan pembelajaran dan SM (31\%) merupakan kategori 
kedua yang banyak dipilih. Hal ini menunjukkan bahwa respon guru terhadap Buku Guru mememiliki kecenderungan positif dilihat dari komponen kompetensi/ tujuan pembelajaran.

2) Respon Komponen Materi/ Pengalaman Belajar

Respon guru SD terhadap penggunaan Buku Guru dalam menyusun Rencana Pelaksanaan Pembelajaran (RPP) pada implementasi Kurikulum 2013 pada komponen materi/ pengalaman belajar dapat

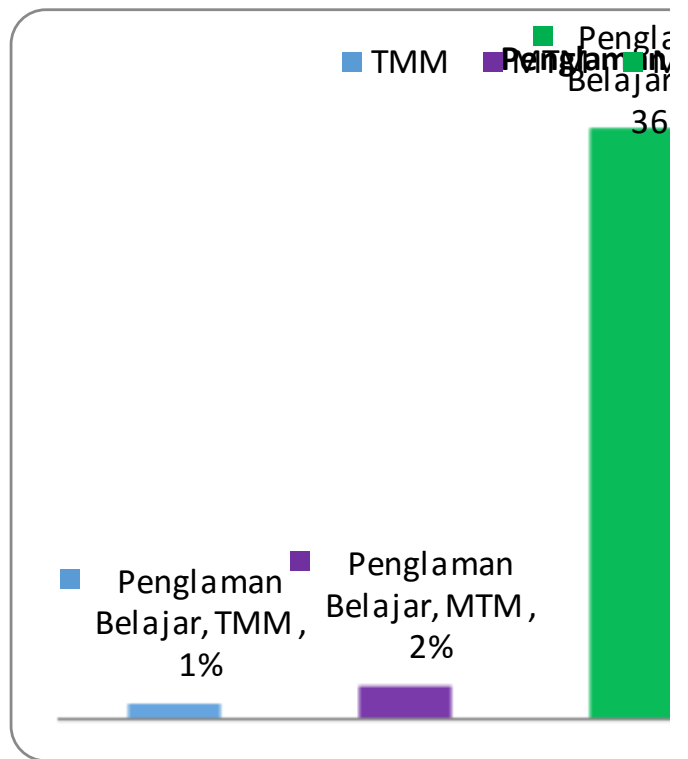

Gambar 3 Respon Guru terhadap Buku Guru pada Komponen Materi/ Pengalaman Belajar

Berdasarkan gambar di atas dan dilihat dari rata-rata respon, kategori MM (36\%), SMM (38\%), dan SMSM (28\%) merupakan kategori yang banyak dipilih oleh para guru pada komponen materi/ pengalaman belajar. Hal ini menunjukkan bahwa respon guru terhadap Buku Guru dikategorikan positif. Hal ini ditunjukkan dengan rata-rata respon guru terhadap Buku Guru sebanyak $36 \%$ pada kategori MM, 34\% sangat SMM, dan $28 \%$ SMSM. Dari enam kabupaten yang menjadi sampel, respon guru dari Kabupaten Bandung (39\% SMM dan $32 \% 7 \%$ SMSM), Kabupaten Bogor (50\% SMM dan 30\% SMSM) dan Kuningan (24\% SMM dan 50\% SMSM) yang lebih positif dibandingkan dengan kabupaten lainnya pada komponen materi/ pengalaman belajar. mememiliki kecenderungan positif dilihat dari komponen materi/ pengalaman belajar.

3) Respon Komponen Metode/ Langkah Pembelajaran

Respon guru SD terhadap penggunaan Buku Guru dalam menyusun Rencana Pelaksanaan Pembelajaran (RPP) pada 
implementasi Kurikulum 2013 pada komponen metode/ langkah pembelajaran dapat dikategorikan positif. Hal ini ditunjukkan dengan rata-rata respon guru terhadap Buku Guru

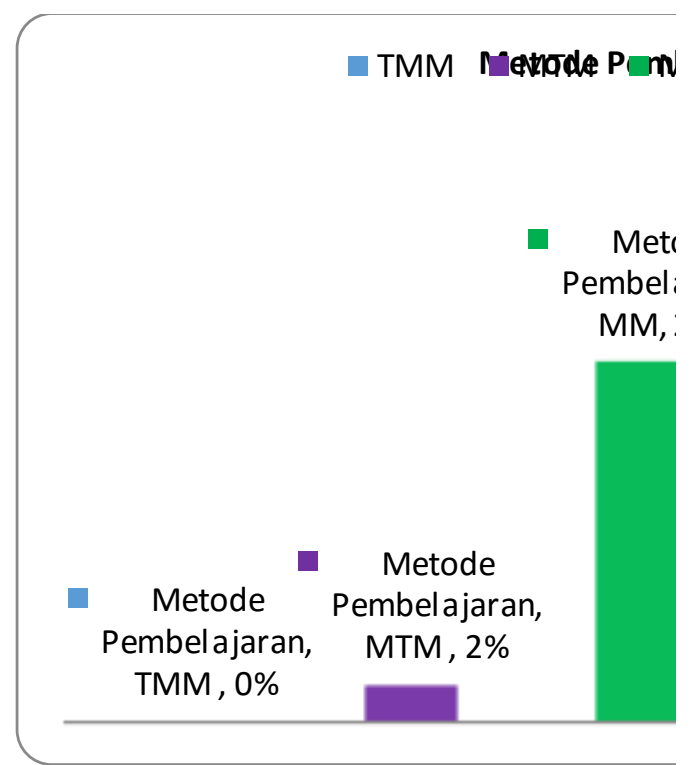

Gambar 4 Respon Guru terhadap Buku Guru

pada Komponen Metode/ Langkah Pembelajaran

Berdasarkan gambar di atas dan dilihat dari rata-rata respon, kategori SMM (42\%) merupakan kategori yang banyak dipilih oleh para guru pada komponen metode/ langkah pembelajaran dan SMSM (31\%) merupakan kategori kedua yang banyak dipilih. Hal ini menunjukkan bahwa respon guru terhadap Buku Guru mememiliki kecenderungan positif dilihat dari komponen metode/ langkah pembelajaran.

4) Respon Komponen Penilaian Respon guru SD terhadap penggunaan Buku Guru dalam sebanyak $24 \%$ pada kategori MM, 42\% SMM, dan 31\% SMSM. Dari enam kabupaten yang menjadi sampel, semua respon guru berada pada kategori sangat positif. menyusun Rencana Pelaksanaan Pembelajaran (RPP) pada implementasi Kurikulum 2013 pada komponen penilaian dapat dikategorikan positif. Hal ini ditunjukkan dengan rata-rata respon guru terhadap Buku Guru sebanyak $23 \%$ pada kategori MM, 42\% sangat SMM, dan $29 \%$ SMSM. Dari enam kabupaten yang menjadi sampel, hampir semua respon guru berada pada kategori sangat positif, kecuali respon guru dari Kabupaten Majalengka (31\% SMM dan 17\% SMSM) pada komponen penilaian. 
TMM

MTNen"lai

- Penilaia

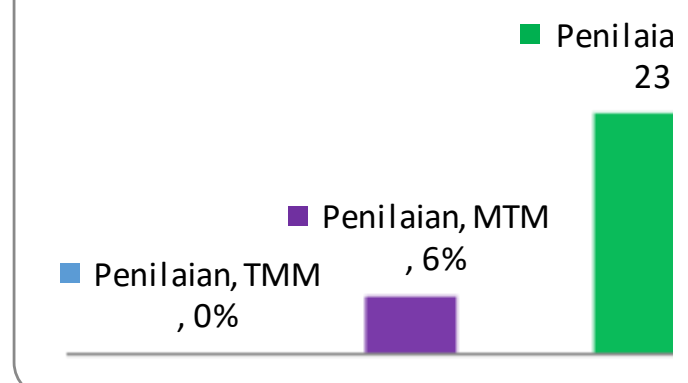

Berdasarkan gambar di atas dan dilihat dari rata-rata respon, kategori SMM (42\%) merupakan kategori yang banyak dipilih oleh para guru pada komponen penilaian dan SMM (29\%) merupakan kategori kedua yang banyak dipilih. Hal ini menunjukkan bahwa respon guru terhadap Buku Guru mememiliki kecenderungan positif dilihat dari komponen penilaian.

Jadi, berdasarkan paparan di atas, data hasil penelitian menunjukkan bahwa respon guru SD terhadap penggunaan Buku Guru dalam menyusun Rencana Pelaksanaan Pembelajaran (RPP) pada implementasi Kurikulum 2013 per komponen berada pada kategori positif. Hal ini didasarkan pada ratarata respon kategori SMM dan SMSM lebih dari 50\%.

\section{Analisis Hasil Penelitian}

Terkait dengan ada tidaknya perbedaan respon guru SD terhadap penggunaan Buku Guru dalam menyusun Rencana Pelaksanaan Pembelajaran (RPP) pada implementasi Kurikulum 2013 antar kabupaten dan antar komponen, dilakukan uji perbedaan dengan menggunakan pengujian Kruskal Wallis. Pengujian ini digunakan karena data tidak memenuhi asumsi distribusi normal dan data yang diuji berskala
Gambar 5 Respon Guru terhadap Buku Guru pada Komponen Penilaian

ordinal. Hasil uji memperlihatkan simpulan sebagai berikut.

\section{a. Hasil Uji Perbedaan Respon Guru Berdasarkan Kabupaten}

Pengujian untuk melihat ada tidaknya perbedaan respon guru terhadap Buku Guru dalam Implementasi Kurikulum 2013 per kabupaten dilakukan dengan dengan menggunakan Kruskal-Wallis Test. Hasil pengujian memperlihatkan informasi bahwa

dari output hasil analisis dapat diketahui statistik uji KruskalWallis $(\mathrm{H})$ adalah 13.448. Dengan $\mathrm{n} 1=19,22,17,18,17,16, \mathrm{n} 2=5$ dan $\mathrm{n} 3=5$ serta $\alpha=0,05$ didapatkan harga kritis statistik uji Kruskal-Wallis adalah 5,78. Karena 6,269 > 5,78 maka keputusan yang diambil adalah menolak $\mathrm{H}_{0}$ dan kesimpulan yang diperoleh adalah ada perbedaan median respon guru terhadap penggunaan $\mathrm{BG}$ pada implementasi kurikulum 2013 antara enam kelompok kabupaten, yaitu Kabupaten Bandung, Bogor, Cirebon, Majalengka, Kuningan, dan Tasikmalaya.

\section{b. Hasil Uji Perbedaan Respon Guru Berdasarkan Komponen}

Pengujian untuk melihat ada tidaknya perbedaan respon guru terhadap Buku Guru dalam Implementasi Kurikulum 2013 per komponen RPP dilakukan dengan 
dengan menggunakan KruskalWallis Test. Hasil pengujian

Tabel 1 Hasil Pengujian Perbedaan Respin Berdasarkan Komponen RPP

\begin{tabular}{|c|l|c|r|}
\hline No & \multicolumn{1}{|c|}{ Komponen } & H-hit & H-tabe \\
\hline 1 & $\begin{array}{l}\text { Kompetensi/T } \\
\text { ujuan } \\
\text { Pembelajaran }\end{array}$ & 5,272 & 11.07 \\
\hline
\end{tabular}

Simpulan hasil pengujian hipotesis sebagai berikut.

Dari output hasil analisis di atas dapat diketahui statistik uji Kruskal-Wallis (H) adalah 5,272. Dengan $\mathrm{n} 1=19, \mathrm{n} 2$ $=22, \mathrm{n} 3=17, \mathrm{n} 4=18, \mathrm{n} 5=17$, dan $\mathrm{n} 6$ $=16 . \alpha=0,05$ didapatkan harga kritis statistik uji Kruskal-Wallis adalah 11.07.

Karena $5.272<11.07$ maka keputusan yang diambil adalah menolak $\mathrm{H}_{1}$ dan kesimpulan yang diperoleh adalah tidak ada perbedaan median respon guru terhadap penggunaan BG pada implementasi kurikulum 2013 tujuan pembelajaran antara enam kelompok kabupaten, yaitu Kabupaten Bandung, Bogor, Cirebon, majalengka, Kuningan, dan Tasikmalaya

Dari output hasil analisis di atas dapat diketahui statistik uji Kruskal-Wallis (H) adalah 16,809. Dengan $\mathrm{n} 1=19, \mathrm{n} 2$ $=22, \mathrm{n} 3=17, \mathrm{n} 4=18, \mathrm{n} 5=17$, dan $\mathrm{n} 6$ $=16 . \alpha=0,05$ didapatkan harga kritis statistik uji Kruskal-Wallis adalah 11.07.

Karena 16,809 > 11.07 maka keputusan yang diambil adalah menerima $\mathrm{H}_{1}$ dan kesimpulan yang diperoleh adalah ada perbedaan median respon guru terhadap penggunaan BG pada implementasi kurikulum 2013 komponen pengalaman belajar antara enam kelompok kabupaten, yaitu Kabupaten Bandung, Bogor, Cirebon, majalengka, Kuningan, dan Tasikmalaya

Dari output hasil analisis di atas dapat diketahui statistik uji Kruskal-Wallis memperlihatkan informasi sebagai

berikut.

\begin{tabular}{|c|c|c|c|c|c|}
\hline & No & Komponen & H-hit & H-tabel & \\
\hline & 2 & $\begin{array}{l}\text { Materi/Pengal } \\
\text { aman Belajar }\end{array}$ & 16,809 & 11.07 & D \\
\hline & 3 & $\begin{array}{l}\text { Metode/Langk } \\
\text { ah }\end{array}$ & 17,713 & 11.07 & \\
\hline I-tabel & $\mathbf{H}_{1}$ & \multicolumn{2}{|c|}{ PembelaJaragimpulan } & & \\
\hline 11.07 & Ditđlak & \multicolumn{2}{|c|}{$\begin{array}{l}\text { Péhiddatnada Perbedina } 055 \\
\text { Persepsi Guru }\end{array}$} & 11.07 & \\
\hline
\end{tabular}

(H) adalah 17,713. Dengan $\mathrm{n} 1=19, \mathrm{n} 2$ $=22, \mathrm{n} 3=17, \mathrm{n} 4=18, \mathrm{n} 5=17$, dan $\mathrm{n} 6$

$=16 . \alpha=0,05$ didapatkan harga kritis statistik uji Kruskal-Wallis adalah 11.07.

Karena 17,713 > 11.07 maka keputusan yang diambil adalah menerima $\mathrm{H}_{1}$ dan kesimpulan yang diperoleh adalah ada perbedaan median respon guru terhadap penggunaan BG pada implementasi kurikulum 2013 komponen metode pembelajaran antara enam kelompok kabupaten, yaitu Kabupaten Bandung, Bogor, Cirebon, majalengka, Kuningan, dan Tasikmalaya

Dari output hasil analisis di atas dapat diketahui statistik uji Kruskal-Wallis (H) adalah 12,285. Dengan $\mathrm{n} 1=19, \mathrm{n} 2$ $=22, \mathrm{n} 3=17, \mathrm{n} 4=18, \mathrm{n} 5=17$, dan $\mathrm{n} 6$ $=16 . \alpha=0,05$ didapatkan harga kritis statistik uji Kruskal-Wallis adalah 11.07.

Karena 12,285 > 11.07 maka keputusan yang diambil adalah menerima $\mathrm{H}_{1}$ dan kesimpulan yang diperoleh adalah ada perbedaan median respon guru terhadap penggunaan BG pada implementasi kurikulum 2013 komponen penilaian antara enam kelompok kabupaten, yaitu: Kabupaten Bandung, Kabupaten Bogor, Kabupaten Cirebon, Kabupaten Majalengka, Kabupaten Kuningan, dan Kabupaten Tasikmalaya.

SIMPULAN DAN REKOMENDASI Berdasarkan paparan pada bab-bab sebelumnya, dapat disimpulkan bahwa 
respon guru SD terhadap penggunaan Buku Guru dalam menyusun Rencana Pelaksanaan Pembelajaran (RPP) pada implementasi Kurikulum 2013 umumnya berada pada kategori positif dan sangat positif.

Secara lebih spesifik dirumuskan simpulan sebagai berikut.

1. Respon guru SD terhadap penggunaan Buku Guru dalam mengembangkan komponen kompetensi atau tujuan pembelajaran pada penyusunan RPP Kurikulum 2013 berada pada kategori positif dan sangat positif.

2. Respon guru SD terhadap penggunaan Buku Guru dalam mengembangkan komponen materi atau pengalaman belajar pada penyusunan RPP Kurikulum 2013 berada pada kategori positif.

3. Respon guru SD terhadap penggunaan Buku Guru dalam mengembangkan komponen metode atau kegiatan pembelajaran pada penyusunan RPP Kurikulum 2013 berada pada kategori positif dan sangat positif.

4. Respon guru SD terhadap penggunaan Buku Guru dalam mengembangkan komponen penilaian pada penyusunan RPP Kurikulum 2013 berada pada kategori positif dan sangat positif.

5. Tidak terdapat perbedaan respon guru terhadap penggunaan Buku Guru dalam mengembangan dan menyusun RPP Tematik dilihat dari perbedaan daerah penugasan (kabupaten).

6. Terdapat perbedaan respon guru terhadap penggunaan Buku Guru mengembangan dan menyusun RPP Tematik dilihat dari komponen materi/ pengalaman belajar, komponen metode/ langkah pembelajaran, dan komponen penilaian, tetapi tidak terdapat perbedaan respon guru terhadap penggunaan Buku Guru mengembangan dan menyusun RPP Tematik dilihat dari komponen kompetensi/ tujuan pembelajaran.

Rekomendasi yang dapat disampaikan terkait dengan hasil penelitian respon guru SD terhadap penggunaan Buku Guru dalam menyusun Rencana Pelaksanaan Pembelajaran (RPP) pada implementasi Kurikulum 2013 ini sebagai berikut.

1. Dainjurkan guru lebih memahami dan mendalami Buku Guru (BG), mulai dari sistematika/ struktur dan konten-konten yang ada di dalamnya. Hal ini penting agar guru lebih lancar dan kompeten dalam mengimplementasikan Kurikulum 2013. Disamping itu guru juga mungin dapat menemukan berbagai hal yang belum sempurna yang ada dalam BG karena BG pada prinsipnya sebagai "dokumen hidup" yang dapat direvisi dan disempurnakan kembali.

2. Keberadaan Buku Guru (BG) pada implementasi Kurikulum 2013 dinilai telah banyak membantu guru dalam merencanakan, melaksanakan, dan menilai pelaksanaan pembelajaran. Dengan demikian adanya BG telah membantu meringankan tugas guru, untuk itu guru dapat melakukan kegiatan penyusunan dan pengembangan lain, misalnya: menyusun bahan atau materi ajar yang melengkapi dan memperkaya materi ajar yang sudah ada atau memasukkan unsur-unsur potensi lokal dalam pembelajaran, mengembangkan metode lain untuk melengkapi metode yang sudah dicanangkan dalam BG, dan mengembangkan alat evaluasi yang lebih relevan dan sesuai dengan kondisi peserta didik.

3. Disadari bahwa BG merupakan instrumen yang dapat membantu 
guru dalam implementasi Kurikulum 2013, oleh karena itu guru juga harus menjadi agen dalam membantu guru lain dalam memahami struktur dan konten BG. Guru diminta untuk membantu guru lain yang belum mahir menggunakan BG dan diharapkan dengan semakin banyak guru yang mahir menggunakan BG, implementasi Kurikulum 2013 dapat terlaksana dengan optimal.

\section{DAFTAR PUSTAKA}

Ali, M. 2010. Metodologi dan Aplikasi Riset Pendidikan. Bandung: Pustaka Cendekia Utama.

Sawali http://sawali.info/2012/12/07/posisibuku-teks-dalam-rancangankurikulum-2013/

Hamdani dalam http://guraru.org/guruberbagi/buku-ajar-dalam-kurikulum2013/

Hernawan, A.H. dan Susilana, R. 2002. Desain Pembelajaran. Jakarta: Pusat Penerbitan Universitas Terbuka.

Kasmadi, H. 2003. "Peran Buku Teks dalam Pembelajaran" dalam Suara Merdeka, Senin 6 Oktober 2003. Kolom Karangan Khas.

Kemdikbud dalam http://kemdikbud.go.id/kemdikbud/be rita/2817

2006. Pedoman Memilih dan Menyusun Bahan Ajar. Jakarta: Depdiknas-Direktorat SMP.

Marsh, C. J. 2004. Key Concepts for Understanding Curriculum, 3rd edition. Oxon: RoutledgeFalmer, hal. $65-75$

Nawangsari, T. 2013. "Perbandingan Berganda Sesudah Uji KruskalWallis" dalam Prosiding Seminar Nasional Matematika dan Pendidikan Matematika FMIPA UNY di Yogyakarta, 9 November 2013. ISBN : $978-979-16353-9$ - 4. Yogyakarta: FPMIPA.

Ornstein, A.C. \& Hunkins, F.P. 1988. Curriculum : Foundations, Principles, and Issues, Singapore : Allyn \& Bacon.

Permendiknas Nomor 2 Tahun 2005 tentang Buku.

Permendikbud Nomor 71 Tahun 2013 tentang Buku Teks Pelajaran dan Buku Panduan Guru untuk Pendidikan Dasar dan Menengah.

Permendikbud Nomor 81A Tahun 2013 tentang Implementasi Kurikulum.

Sukmadinata, N. S. 2001. Pengembangan Kurikulum: Teori dan Praktek. Bandung: Remaja Rosdakarya.

Susilana, R. (Editor) dkk 2006, Kurikulum dan Pembelajaran. Bandung: Tim Pengembang MKDP Jurusan Kurtekpen FIP UPI Bandung.

Susilana, R. 2010. Pengembangan Bahan Ajar. Bandung: Jurusan Kurtekpen FIP UPI dan PT Kereta Api Indonesia.

Zais, R. S. 1976. Curriculum, Principles and Foundations. New York: Harper and Row Publisher.

Tyler, R. W. 1975. Basic Principles of Curriculum and Instruction. Chicago and London: The University of Chicago Press. 